\title{
The Moderating Effect Of Product Market Competition In The Relationship Between Advertising Expenditures And Sales
}

Yura Kim, Kookmin University, Korea

Jaewoo Joo, Kookmin University, Korea

\begin{abstract}
While the relationship between advertising expenditures and sales has been much discussed, whether product market competition affects their relationship has been little examined. We address this question by analyzing the financial performance data of 6,018 companies for 14 years (19972011). Our data analysis supports two hypotheses that (1) increasing advertising expenditures increase sales in the subsequent year and that (2) this effect is stronger when the product market competition is high than when it is low. Our findings advance the academic understanding of advertising effect as well as provide practical implications to advertising managers.
\end{abstract}

Keywords: Advertising Expenditures; Product Market Competition

\section{INTRODUCTION}

\subsection{Research aim}

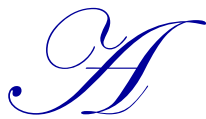

dvertising is one of the most visible marketing expenditures. Over $\$ 60$ billion were allocated to advertising media by the top 200 consumer products advertisers in 1995 alone (Graham and Frankenberger 2000). Managers allocate a large amount of their resources to advertising in order to increase sales, and ultimately, firm value. Therefore, the relation between advertising expenditures and a firm's financial performance has been extensively investigated over time and across industries in the areas of marketing, accounting, and finance. However, researchers have not reached clear answers to some questions regarding advertising. These questions include, for instance, whether advertising expenditures increase firm value (Chauvin and Hirschey 1993; Green et al. 1995; Joshi and Hanssens 2010; Luo and De Jong 2012; Tellis and Weiss 1995), why firms invest in advertising with limited sales responses (Osinga et al. 2011), and what the short-term impact of super bowl advertising is on stock prices (Eastman et al. 2010), to name a few.

In particular, researchers have shown significant interest in what determines the commercial impact of advertising expenditures, for example, their effects on sales, market share, and firm value. One of the most actively discussed topics is whether firms should spend more on advertising during recessions or not (Kamber 2002; Meldrum and Fewsmith, Inc 1979; Vaile 1926).

\subsection{Initial assumptions of the paper}

There are many reasons for and against advertising during a recession. One of the most compelling reasons against advertising during a recession is that sales are likely to be lower during a recession than during an expansion. In contrary, most firms tend to cut back on advertising during a recession, which reduces noise and increases the effectiveness of advertising. Therefore, the firms invest in advertising during a recession can enjoy higher sales and market share afterwards. This is a simple but strong refutation of the theory for cutting back on advertising during a recession. 
Several empirical studies support the premise that increasing advertising expenditure during a recession results in sales increase. For example, Vaile (1926) conducted an analysis of the effect of advertising on sales from 1920 to 1924, a period that encompasses the 1921 recession. They compared the sales of firms that increased their advertising, to those that decreased their advertising, and those that did no advertising. They found that increasing advertising during a recession results in increasing sales. On the other hand, decreasing advertising during a recession results in decreasing sales, more so than for categories that did no advertising at all. A similar finding was obtained from Meldrum and Fewsmith, Inc (1979). They conducted a survey of managers in 4786 firms to examine the effectiveness of advertising on sales during the 1974-1975 recession. They analyzed the impact on sales in 5 subsequent years in response to whether firms cut or maintained their advertising expenditures in 1974 and 1975 using the 177 responses obtained from 143 firms. The authors found a strong impact on market share of maintaining advertising expenditure. In the years that followed the recession, firms which did not cut advertising expenditures experienced higher sales than those companies that cut advertising expenditures in 1974, or 1975, or both. Moreover, the sales of the former firms kept growing for up to 4 years after recession. More recently, Kamber (2002) conducted a study on the effect of advertising on sales of 822 firms over a 6-year period that encompassed the 1990-91 recession. He also obtained the findings that support for the hypothesis that increasing advertising during a recession helps to increase sales.

\subsection{Reasoning for the focus of the paper}

In the present work, we borrow the underlying mechanism of why firms should not cut back on advertising during a recession and then make an argument that advertising is effective when the market is crowded more than when the market is not.

\subsection{Research objectives}

We borrow advertising literature and analyze firm data to achieve two objectives. First, we identify whether increasing advertising expenditures increase sales in the subsequent year. Secondly and more importantly, we examine whether the relationship between advertising expenditures and sales is moderated by Product Market Competition (hereafter PMC) or the degree to which an industry is competitive. In other words, we test whether increasing advertising expenditures in highly competitive industries increases sales more strongly than in less competitive industries.

\subsection{Originality of the paper, expected results and contribution to knowledge}

To the best of our knowledge, PMC has been little discussed in the work on advertising. Although industry concentration has been examined in a few prior works, it has been either considered as an outcome of advertising expenditures (Eckard 1987) or controlled for other analysis (Rao et al. 2004).

We shed a light on PMC in order to advance the understanding in an area of marketing inquiry that has been traditionally underserved: whether PMC affects advertising effectiveness. In order to answer this question, we analyze the financial data of 6,018 firms for 14 years (1997-2011). Our analysis of 35,812 observations enables us to test advertising effects more rigorously than existing empirical studies (e.g., 71 observations in Ben-Zion (1978) or 17,577 observations in Cheng and Chen (1997)). The remainder of the present work is organized into six sections. The next section provides a theoretical framework and research model. Then, literature review that pertains to advertising and product market competition and support of the research hypotheses are listed in section 3 . We lay out the methodology in section 4 and research results in section 5. In section 6, we discuss the findings with academic contribution, managerial implications, and the directions for future research.

\section{THEORETICAL FRAMEWORK AND RESEARCH MODEL}

\subsection{Theory and theoretical perspective}

Advertising expenditures are commonly expected to increase not only firms' market shares and their sales but also improve their stock returns without changing their sales (Srinivasan and Hanssens 2009). For instance, Rao 
et al. (2004) examined which branding strategies improve firm values and found that advertising expenditures are positively associated with firm values. Wang et al. (2009) also demonstrated that advertising expenditures create sustained firm value in several industries including household audio and video equipment, variety stores, and grocery stores, to name a few. More recently, Tikoo and Ebrahim (2010) found evidence that investors prefer advertising investments over R\&D investments during an economic downturn. They found that ERC (Earnings Response Coefficient) is greater for a firm that increases its advertising expenditures and decreases its R\&D expenditures than a firm that decreases its advertising expenditures and increases R\&D expenditures. According to the meta-analysis of 15 empirical studies conducted by Conchar et al. (2005), "models that consider A\&P (Advertising \& Promotion) effect on the market value of the firm yield a significant and positive coefficient of A\&P spending" (p. 453). This finding is consistent with Chauvin and Hirschey's (1993) argument that "spending on advertising can be viewed as a form of investment in intangible assets with predictably positive effects on future cash flows" (p. 128).

\subsection{Definitions and assumptions}

In the present work, we test, first, the relationship between advertising expenditures and sales and, secondly, the moderating effect of PMC (Product Market Competition) on its relationship. Therefore, we need to define two variables; they are advertising expenditures and PMC. First, advertising expenditures is defined as the ratio of the advertising expenditures to the total asset of a firm. We borrow this definition from the prior works on the topic of advertising expenditures (Chauvin and Hirschey 1993; Green et al. 1995; Joshi and Hanssens 2010; Luo and De Jong 2012; Tellis and Weiss 1995). Secondly, PMC is defined as the degree to which an industry is competitive. We define PMC by borrowing Karuna's (2007) work in which PMC consists of three components; the first component is existing competition or the degree to which existing firms in the industry compete each other, the second component is potential competition or the degree to which the firms that are interested in entering the industry compete each other, and the last component is product substitutability or the degree to which a firm incurs operating cost in order to generate sales.

\subsection{Structural model (a table presenting the constructs, definitions and references)}

\begin{tabular}{|l|l|l|}
\hline \multicolumn{1}{|c|}{ Variable } & \multicolumn{1}{|c|}{ Definition } & \multicolumn{1}{|c|}{ Reference } \\
\hline Advertising expenditures & $\begin{array}{l}\text { Ratio of the advertising expenditures to } \\
\text { the total asset }\end{array}$ & Chauvin and Hirschey 1993 \\
\hline PMC (Product Market Competition) & $\begin{array}{l}\text { the degree to which an industry is } \\
\text { competitive }\end{array}$ & Karuna 2007 \\
\hline
\end{tabular}

See Figure 1 for research framework

\section{LITERATURE REVIEW AND SUPPORT OF THE REEARCH HYPOTHESES}

\section{Advertising Expenditure}

Advertising expenditures are commonly viewed to have a positive relationship with firms' market performance. This notion has long been supported by a list of empirical studies. For example, Peles (1970) demonstrated that sales in a given year are associated with advertising expenditures up to 3 years prior to that year. Green et al. (1995) also reported that word processing suppliers benefit from advertising when they enter the software industry. Dekimpe and Hanssens (1995) apply a time-series methodology to monthly data from a home improvement retail chain and conclude that advertising effects "did not dissipate within a year" (p. 18). Graham and Frankenberger (2000) estimated the contribution of advertising to market values over the 5 years from 1990 through 1994.

However, it has been also reported that advertising expenditures do not increases sales. For instance, Lodish et al. (1995) conducted a large-scale, single-source study and concluded that increased advertising weights increased sales in only $33 \%$ of cases for established brands and in 55\% of cases for new brands. Tellis and Weiss (1995) found no effects from advertising as well. 
Note that the research that fails to show the positive impact of advertising expenditures has limitations to generalize to some extent. This is because some researchers collected data from a single product category and others analyzed advertising expenditures and sales within a relatively short time span or in the same year. Therefore, in the present work, we hypothesize that increased advertising expenditures will increase sales in the subsequent year.

Hypothesis 1: Sales increase when advertising expenditures increase.

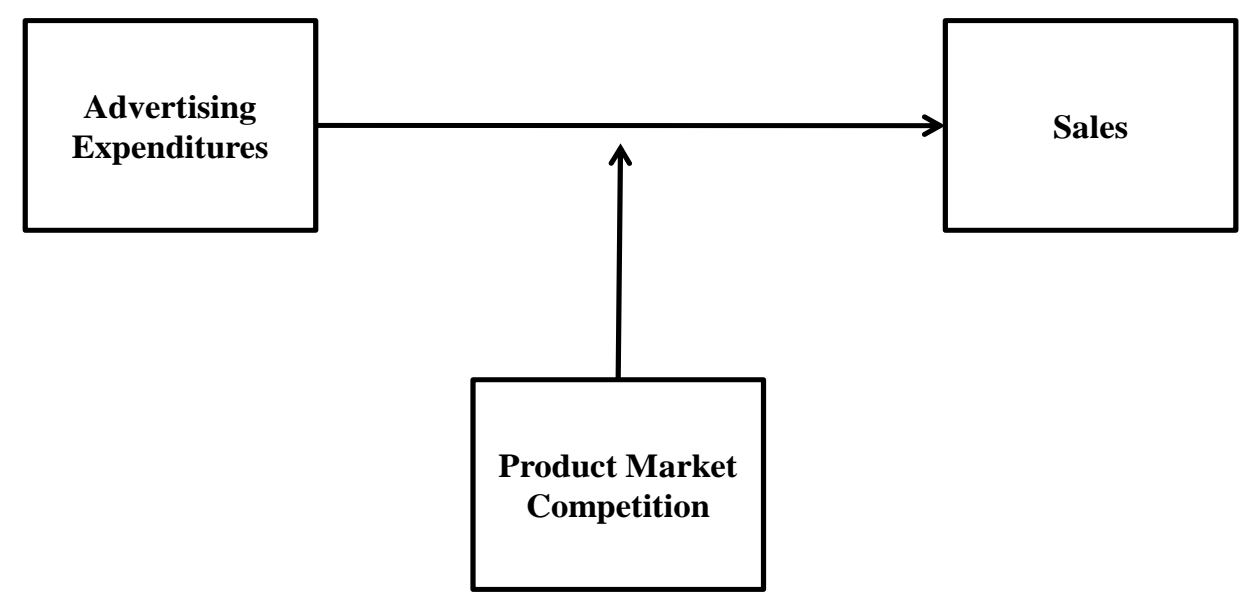

Figure 1. Research Framework

\section{Product Market Competition (PMC)}

Some researchers go beyond demonstrating advertising effects to discover their boundary conditions. First, they studied firm specific variables such as its size or its strategy. For instance, Chauvin and Hirschey (1993) reported that advertising expenditures are concentrated among large firms (e.g., Unilever, Philip Morris, General Motors and Proctor \& Gamble) and that, more importantly, the advertising expenditures of the large firms (sales $\geq$ $\$ 1424.2$ million) are more effective than those of medium firms (\$384 million < sales $<\$ 1424.2$ million). Rao et al. (2004) examined the branding strategies that firms employ and identified that the branding strategies determine the effects of advertising expenditures on value. He found that firm value increases as advertising expenditures increase when a firm follows a "corporate branding strategy" or endorses all or part of the firm's product and service brands using the name of the firm (e.g., Hewlett-Packard, McDonald's, or FedEx). However, no positive relationship exists between advertising expenditures and firm value when a firm follows a "house-of-brands strategy" or uses individual brand names to market its products and services (e.g., Dove and Lipton marketed by Unilever and Pampers and Crest marketed by Procter \& Gamble).

Next, they studied several market variables such as recession or globalization. For example, Vaile (1926) showed that increasing advertising expenditures during a recession results in increasing sales. The identical findings have been replicated from Meldrum and Fewsmith, Inc (1979) and Kamber (2002). Next, it has been also studied whether advertising agencies spend more when their market is global than when their market is local (Nachum and Rolle 1999; Walters et al. 2008). To our best knowledge, however, PMC has not been discussed as the moderating variable of the relationship between advertising expenditures and sales. Instead, PMC is often considered as a variable that should be controlled for while examining advertising effects. Conchar et al. (2005) found that in seven out of fifteen studies, researchers controlled one form of PMC. 
Differently from prior research, we examine whether PMC determines the effects of advertising expenditures on sales. In particular, we hypothesize that advertising expenditures increase sales more strongly when PMC is high than when it is low. Our hypothesis is supported by marketing literature combining a behavioral approach (understanding consumer behavior towards advertising) and an empirical approach (analyzing financial data for advertising firms). Keller (1993), for instance, suggests that when consumers are exposed to advertising, they create, learn, and reinforce brand knowledge, which in turn becomes the foundation of consumer based brand equity. Accordingly, advertising will be more effective when the market is crowded with competing products and thus consumers have fewer opportunities to develop brand knowledge. Vakratsas and Ambler (1999) also argue that in order for consumers to choose and consume advertised products, consumers should go through experience, affect and cognition. This implies that advertising in a highly competitive market will have different effects compared to advertising in a less competitive market. Based on the arguments above, we present the following hypothesis:

Hypothesis 2: The effect of advertising expenditures on sales increases as PMC (Product Market Competition) increases.

\section{METHODOLOGY}

\subsection{Research method, sample and data collection}

We obtain data from Compustat North America Annual database over the period from 1997 to 2011 and carefully select our sample through four stages. First, we exclude financial institutions (SIC code 6000-6999). They are typically examined separately as their financial ratios and valuations metrics are different to those of general industries. It should be noted that the loan ratio, adequacy ratio, and liquidity ratio of financial institutions are strictly regulated and their financial leverage and receivables deflated by total assets are often meaningless (Fields et al. 2004). Second, we exclude regulated industries (SIC code 4800-4900) as their characteristics differ from those of other industries. Third, we further eliminate observations with missing variables of interests for our regression models. Finally and most importantly, we restrict the sample to the firms with advertising expenditures available on Compustat database. Our effort leads us to have a sample of 35,812 firm-year observations and 6,018 individual firms. The descriptive statistics of our sample are in Table 1 .

TABLE 1

Descriptive Statistics

\begin{tabular}{lccccccccc}
\hline \multicolumn{1}{c}{ Variable } & Mean & Median & Std. dev. & P25 & P75 & Skewness & Kurtosis & [95\% conf. interval] \\
\hline SALES & 1.440 & 1.252 & 0.924 & 0.806 & 1.838 & 1.405 & 5.551 & 1.431 & 1.450 \\
ADV & 0.045 & 0.021 & 0.067 & 0.008 & 0.051 & 3.208 & 14.830 & 0.044 & 0.045 \\
SIZE & 4.972 & 4.901 & 2.393 & 3.272 & 6.558 & 0.188 & 2.711 & 4.948 & 4.997 \\
ROA & -0.055 & 0.030 & 0.338 & -0.068 & 0.088 & -3.582 & 18.932 & -0.059 & -0.052 \\
MB & 2.704 & 1.801 & 4.972 & 0.957 & 3.344 & 2.101 & 16.218 & 2.652 & 2.755 \\
LOSS & 0.370 & 0.000 & 0.483 & 0.000 & 1.000 & 0.538 & 1.289 & 0.365 & 0.375 \\
AGE & 17 & 12 & 13 & 7 & 22 & 1 & 4 & 16.557 & 16.826 \\
HHI & 4192 & 3461 & 2685 & 1981 & 5842 & 1 & 3 & 4163 & 4219 \\
CONC & 0.857 & 0.920 & 0.166 & 0.760 & 1.000 & -1.160 & 3.558 & 0.855 & 0.858 \\
LEADER & 0.492 & 0.000 & 0.500 & 0.000 & 1.000 & 0.031 & 1.001 & 0.487 & 0.497 \\
ENTCOST & 6.697 & 6.766 & 2.300 & 5.125 & 8.499 & -0.328 & 2.649 & 6.673 & 6.721 \\
DIFF & 2.066 & 1.106 & 11.050 & 1.051 & 1.192 & 15.733 & 281.532 & 1.951 & 2.180 \\
\hline SALES & & & & & & & & &
\end{tabular}

SALES $=$ sales of a firm in year $\mathrm{t}$; $\mathrm{ADV}=$ advertising expenditures in year $\mathrm{t}-1$; ROA $=$ return on assets; SIZE $=$ natural logarithm of firm's total assets; $\mathrm{MB}=$ market value of equity / book value of equity; LOSS = 1 if income before extraordinary items is less than zero, and 0 otherwise $; \mathrm{HHI}=$ the sum of the squared market shares in an industry; CONC = four-firm concentration ratio measured by sales in an industry; LEADER = indicator variable equal to 1 if the firm is one of the largest four firms in an industry; ENTCOST = gross value of property, plant and equipment to total assets weighted by each firm's market shares in industry; DIFF = sales/ operating costs weighted by each firm's market share in industry. More detailed variable definitions are in Appendix A

On average, firms spend $4.5 \%$ of total assets on advertising. Market value of equity is 2.7 times more than book value of equity. About $37 \%$ of sample firms report loss in the current period. Firms' mean return on assets is negative $5.5 \%$ while the median return on assets is positive 3\%. This means that firms' return on assets is skewed to 
the left. An average age of the firms in our sample is 17 years. Compared to Karuna (2007), entry costs, which measure the minimum level of investment to enter the market,show similar statistics, but four-firm concentration in our sample is a bit higher and price-margin ratio is lower.

The skewness statistics indicates that sales (SALES), lagged advertising expenditures (ADV), market-tobook ratio (MB), firm size (SIZE), loss indicator variable (LOSS), and firm age (AGE) are all positively skewed while return on assets (ROA) is negatively skewed. Also, the kurtosis coefficients of return on assets (ROA) and market-to-book ratio (MB) are 18.93 and 16.22, insinuating higher than normal peak. The other variables show moderate kurtosis.

\subsection{Measures and measurement of variables}

We measure advertising expenditures as the ratio of advertising expenditures to the total assets of the firm. It is a dummy variable equal to 1 if the firm's advertising expenditures exceed industry median based on 2-digit SIC code, and 0 otherwise (HighAD).

Prior literature has focused on a single measure of market competition, which measures sales concentration in the market. In this paper, we incorporate five proxies of market competition in order to capture different nature of industry competition. More specifically, following Karuna (2007) we employ existing competition, potential competition, and product substitutability. Three proxies - industry concentration, four-firm concentration ratio and leader firm indicator - are considered to measure the competitiveness of the existing market. We estimate entry costs to measure potential competitiveness, and employ price-cost margin to measure product substitutability.

For the competitiveness of the existing market, prior literature focuses on industry concentration and mostly measures it using a single measure called Herfindahl-Hirschman Index (HHI). Although HHI is widely used, we include two additional measures in order to take into account whether the market is dominated by several large firms or equally distributed. One of the two measures is four-firm concentration ratio which indicates the degree to which the four largest firms dominate the market. The other is leader firm dummy variable, which indicates whether the firm is one of the four largest firms.

Beside the competitiveness of the existing market, we employ two additional measures - entry costs and price-cost margin - to consider potential competitiveness and product substitutability (Karuna 2007). First, entry costs are the minimum investments that a firms needs to commit to enter the market. When a firm operates in the market where initial costs to enter the market are high, the firm faces potentially less threats from outside rivals. Thus, high entry costs deter potential rivals to enter the market. Following Karuna (2007), we measure entry costs by using the level of property, plant, and equipment for a firm weighted by its market share in the market. Second, price-cost margin indicates how much operating costs a firm should incur in order to generate sales. It is computed as sales divided by operating costs of a firm and weighted by a firm's market share in industry. Where the margin is lower, more substitutes exist in industry. That is, price-cost margin measures the level of price competition. Overall, the market is more concentrated as the margin increases, and when a firm operates in a market close to perfect competition, the product has more substitutes and its price closely approximates cost. Management incentives are stronger where the market is competitive.

In this paper, we conjecture that product market competition influences firm's advertising expense and ultimately sales. However, the relationship between advertising and sales are likely to be affected by firm-specific measures and we control for firm characteristics in our tests. We include return on assets (ROA) and a loss indicator variable (LOSS) to control for profitability of a firm. ROA is a ration of a firm's income before extra ordinary items to total assets. LOSS is an indicator variable that is equal to 1 if a firm has a loss in the current period and 0 otherwise. A firm's advertising expense is expected to be closely related to the firm size. We use the natural logarithm of a firm's total assets to control for the size of a firm. Market-book ratio (MB) is the ratio of book value and market value of equity, and is a proxy for growth opportunity as well as the firm size. The age of a firm (AGE) measures a life cycle of a firm such as introduction, maturity, and decline. Whether a firm is growing or declining is likely to affect its advertising expense and sales increase. 


\subsection{Statistical analyses}

To test whether a firm's advertising expenditures effectively increase subsequent sales, we estimate the following OLS regression;

$\operatorname{SALES}_{t}=\alpha_{0} A D V_{t-1}+\alpha_{1} R O A_{t}+\alpha_{2} \operatorname{SIZE}_{t}+\alpha_{3} M B_{t}+\alpha_{4} L O S S_{t}+\alpha_{5} A G E_{t}+\varepsilon$,

where $S A L E S_{t}$ is current period sales, $A D V_{t-1}$ is prior-year advertising expenditures, ROA is return on assets, SIZE is a natural logarithm of total assets, MB is market-to-book ratio, LOSS is an indicator variable equal to 1 if a firm has negative income in the current period and 0 otherwise, and AGE is firm age. We run equation (1) by six industry groups to examine whether the influence of advertising on sales is different across industries.

To investigate the moderating role of product market competition on the relationship between advertising expenditures and sales, we estimate the following OLS regression as well;

$S A L E S_{t}=\alpha_{0} A D V_{t-1}+\alpha_{1} H I G H_{-} C O M P_{t}+\alpha_{2} A D V t_{-1} * H I G H_{-} C O M P_{t}+\alpha_{3} R O A_{t}$

$+\alpha_{4} S I Z E_{t}+\alpha_{5} M B_{t}+\alpha_{6} L_{S S S_{t}}+\alpha_{7} A G E_{t}+\varepsilon$

where HIGH_COMP ${ }_{t}$ is an indicator variable equal to 1 if an $\mathrm{HHI}$ is higher than median value and 0 otherwise. We also include an interaction term $\left(\mathrm{ADVt}_{-1} * \mathrm{HIGH}_{-} \mathrm{COMP}_{\mathrm{t}}\right)$ in order to examine the influence of HHI on the effect of advertising expenditures on subsequent sales. All other variable are the same as the regression equation (1) above. As explained, we use five proxies of product market competition. Because they capture different aspects of market competitiveness, we analyze each of five different relationships between product market competition and advertising effect on sales separately. Therefore, we replace HIGH_COMPt with the other four product market competition measures (LEADER, HIGH_CONC, HIGH_MARGIN, and HIGH_COST) and continue identifying their interactions.

In this study, the variance inflationary factor (VIF) for each explanatory variable was used to check collinearity. VIF scores ranged between 1.02 and 1.63, indicating that there are no multi-collinearity problems,

\section{RESEARCH RESULTS}

\subsection{Descriptive statistics}

We provide correlations among advertising expenditures, sales, product market competition, and the remaining control variables in Table 2. According to the report, sales (SALES) is positively correlated with 1-year lagged advertising expenditures (ADV), return on assets (ROA), and market-to-book ratio (MB). However, sales is negatively correlated with firm size (SIZE), loss indicator variable (LOSS) and firm age (AGE). Among the product market competition measures, a Herfindhal-Hirschman index (HHI) is positively correlated with four-firm concentration ratio (CONC) and negatively correlated with entry cost (ENTCOST). This may indicate that market is more competitive when costs to enter the market are large.

\subsection{Linear correlations}

First, we test whether sales increases when advertising expenditures increase. Table 3 presents the results of the effect of advertising expenditures on sales. The coefficient of $\mathrm{ADV}_{\mathrm{t}-1}$ is positive and significant at the $1 \%$ level. This suggests that increasing advertising expenditure increases sales. Additionally, ROA and market-to-book ratio have a positive relationship with sales whereas loss firms are negatively related with sales. Table 4 reports results of equation (1) separately for 6 different industry groups. The positive relationship between advertising expenditures and sales is found throughout different industries. Therefore, our hypothesis 1 is supported. 
TABLE 2. Correlations Matrix

Panel A: Correlation among main and control variables

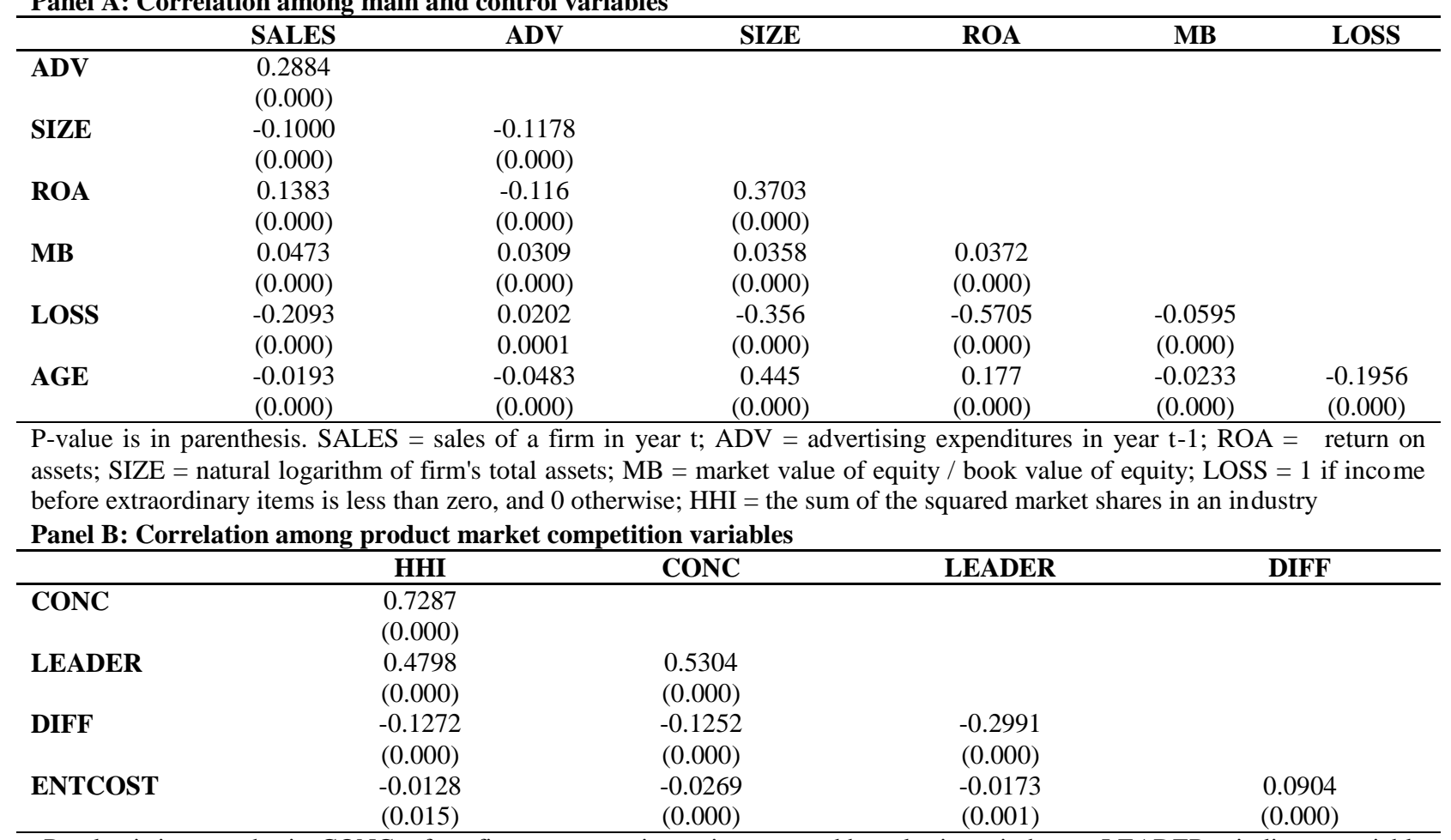

P-value is in parenthesis. CONC $=$ four-firm concentration ratio measured by sales in an industry; LEADER = indicator variable equal to 1 if the firm is one of the largest four firms in an industry; ENTCOST = gross value of property, plant and equipment to total assets weighted by each firm's market shares in industry; DIFF = sales/ operating costs weighted by each firm's market share in industry. More detailed variable definitions are in Appendix A.

Next, we test the role of product market competition on the effect of advertising expenditures on sales. Since we incorporate five different proxies to measure product market competition, we analyze and report five interactions individually. Table 5 presents what roles product market competition plays between advertising expenditures and sales. We employ market concentration measure (HHI) in Model (1) and (2). In Model (2), the coefficient of an interaction term, ADVt-1 ${ }^{*} \mathrm{HIGH} \_\mathrm{COMPt}$, is positive and statistically significant at the $1 \%$ level. This may be interpreted that when the market is close to perfect competition, advertising effect is high. In Model (3) and (4), we consider four-firm concentration measure. The coefficient of CONC and HiGH_CONC are both positive. This seems to indicate that advertising increases sales more in industries with a few dominating firms. However, the coefficient of an interaction term, ADVt-1 *HIGH_CONCt, (-1.336) is negative and significant. This can be interpreted that when few firms dominate a market, overall effect of advertising on sales is low. In other words, managers in this market have low motivations to advertise their products or services in order to increase sales. Both model (5) and (6) include an indicator variable leader in the test. The coefficient of an interaction term, ADVt-1 * LEADER, is negative and statistically significant. This suggests that when a firm is one of the four largest firms, advertising effect is low. 
TABLE 3

Effect of Advertising Expenditures on Sales Increase

\begin{tabular}{|c|c|c|}
\hline \multirow[b]{2}{*}{ VARIABLES } & \multicolumn{2}{|c|}{ Dependent Var. $=$ SALES $_{t}$} \\
\hline & Model (1) & Model (2) \\
\hline $\mathrm{ADV}_{\mathrm{t}-1}$ & $3.949 * * *$ & $3.881 * * *$ \\
\hline $\mathrm{ROA}_{\mathrm{t}}$ & & $0.324 * * *$ \\
\hline $\operatorname{SIZE}_{\mathrm{t}}$ & & $\begin{array}{c}-0.076^{* * *} \\
(-14.16)\end{array}$ \\
\hline $\mathrm{MBt}$ & & $\begin{array}{c}0.005 * * * \\
(3.64)\end{array}$ \\
\hline LOSS $_{\mathrm{t}}$ & & $\begin{array}{c}-0.405 * * * \\
(-22.00)\end{array}$ \\
\hline $\mathrm{AGE}_{\mathrm{t}}$ & & $\begin{array}{l}0.001 \\
(1.34)\end{array}$ \\
\hline Constant & $\begin{array}{c}1.263 * * * \\
(92.57)\end{array}$ & $\begin{array}{c}1.772 * * * \\
(56.94)\end{array}$ \\
\hline No. ob Obs. & 35,812 & 35,812 \\
\hline R-squared & 0.083 & 0.163 \\
\hline F-value & $440.96 * * *$ & $279.34 * * *$ \\
\hline
\end{tabular}

TABLE 4

Effect of Advertising Expenditures on Sales Increase by Industry

\begin{tabular}{|c|c|c|c|c|c|c|}
\hline \multirow[b]{3}{*}{ VARIABLES } & \multicolumn{6}{|c|}{ Dependent Var. = SALES $_{t}$} \\
\hline & Model (1) & Model (2) & Model (3) & Model (4) & Model (5) & Model (6) \\
\hline & $\begin{array}{c}\text { Mining \& } \\
\text { Const. }\end{array}$ & Manufacturing & Services & Retail & Transportation. & Other \\
\hline \multirow{2}{*}{$\mathrm{ADV}_{\mathrm{t}-1}$} & $7.058 * * *$ & $2.974 * * *$ & $7.937 * * *$ & $3.127 * * *$ & $3.177 * * *$ & $6.303 * * *$ \\
\hline & $(3.41)$ & $(13.66)$ & $(3.42)$ & $(7.23)$ & $(12.49)$ & (4.82) \\
\hline \multirow[t]{2}{*}{ ROA } & 0.330 & $0.394 * * *$ & $0.872 * * *$ & 0.268 & $0.159 * * *$ & 0.095 \\
\hline & $(1.05)$ & (7.99) & $(3.25)$ & $(1.62)$ & $(2.77)$ & $(0.60)$ \\
\hline \multirow[t]{2}{*}{ SIZE } & -0.047 & $-0.089 * * *$ & $-0.181 * * *$ & -0.018 & $-0.132 * * *$ & $-0.075 * * *$ \\
\hline & $(-1.16)$ & $(-16.49)$ & $(-4.16)$ & $(-0.94)$ & $(-13.22)$ & $(-2.71)$ \\
\hline \multirow[t]{2}{*}{ MB } & $0.037 * *$ & $0.006 * * *$ & 0.003 & $0.018 * * *$ & $0.011 * * *$ & 0.005 \\
\hline & $(2.03)$ & $(3.26)$ & $(0.35)$ & $(3.51)$ & $(4.42)$ & $(0.51)$ \\
\hline \multirow[t]{2}{*}{ LOSS } & $-0.527 * * *$ & $-0.346^{* * *}$ & 0.043 & $-0.346 * * *$ & $-0.439 * * *$ & $-0.335 * *$ \\
\hline & $(-6.17)$ & $(-16.77)$ & $(0.44)$ & $(-6.26)$ & $(-13.44)$ & $(-2.37)$ \\
\hline \multirow[t]{2}{*}{ AGE } & -0.001 & $0.002 *$ & $0.009 * *$ & -0.003 & $0.005^{*}$ & 0.002 \\
\hline & $(-0.12)$ & (1.85) & (2.27) & $(-0.87)$ & (1.70) & $(0.31)$ \\
\hline \multirow[t]{2}{*}{ Constant } & $1.346 * * *$ & $1.716 * * *$ & $2.189 * * *$ & $2.197 * * *$ & $1.781 * * *$ & $1.312 * * *$ \\
\hline & $(5.37)$ & $(56.48)$ & $(7.81)$ & $(20.08)$ & $(28.66)$ & $(5.91)$ \\
\hline No. of Obs. & 662 & 18,843 & 579 & 6,966 & 8,243 & 379 \\
\hline R-squared & 0.252 & 0.201 & 0.276 & 0.087 & 0.201 & 0.231 \\
\hline F-value & $17.89 * * *$ & $167.11 * * *$ & 7.76 *** & $26.44 * * *$ & $119.49 * * *$ & $8.59 * * *$ \\
\hline
\end{tabular}


TABLE 5

Influence of existing product market competition on the effect of Advertising Expenditures on Sales Growth

\begin{tabular}{|c|c|c|c|c|c|c|}
\hline VARIABLES & Model (1) & Model (2) & $\begin{array}{l}\text { Dependent } \\
\text { Model (3) }\end{array}$ & $\begin{array}{l}=\text { SALES }_{\mathrm{t}} \\
\text { Model (4) }\end{array}$ & Model (5) & Model (6) \\
\hline $\mathrm{ADV}_{\mathrm{t}-1}$ & $\begin{array}{c}3.874 * * * \\
(20.80)\end{array}$ & $\begin{array}{c}3.353 * * * \\
(14.67)\end{array}$ & $\begin{array}{l}3.880 * * * \\
(20.76)\end{array}$ & $\begin{array}{c}4.515 * * * \\
(18.11)\end{array}$ & $\begin{array}{c}3.876 * * * \\
(20.72)\end{array}$ & $\begin{array}{c}4.375 * * * \\
(18.22)\end{array}$ \\
\hline $\mathrm{HHI}_{\mathrm{t}}$ & $\begin{array}{l}-0.034 \\
(-0.90)\end{array}$ & & & & & \\
\hline $\mathrm{HIGH}_{-} \mathrm{COMP}$ t & & $\begin{array}{l}-0.017 \\
(-0.76)\end{array}$ & & & & \\
\hline $\begin{array}{l}\mathrm{ADV}_{\mathrm{t}-1} \\
* \mathrm{HIGH} \mathrm{COMP}_{\mathrm{t}}\end{array}$ & & $\begin{array}{c}0.963 * * * \\
(2.88)\end{array}$ & & & & \\
\hline $\mathrm{CONC}_{\mathrm{t}}$ & & & $\begin{array}{c}0.172 * * * \\
(3.01)\end{array}$ & & & \\
\hline HIGH_CONC & & & & $\begin{array}{c}0.085 * * * \\
(3.63)\end{array}$ & & \\
\hline $\begin{array}{l}\mathrm{ADV}_{\mathrm{t}-1} \\
* \mathrm{HIGH} \mathrm{CONC}_{\mathrm{t}}\end{array}$ & & & & $\begin{array}{c}-1.336 * * * \\
(-4.10)\end{array}$ & & \\
\hline LEADER $_{t}$ & & & & & $\begin{array}{c}0.109 * * * \\
(4.77)\end{array}$ & $\begin{array}{c}0.161 * * * \\
(6.43)\end{array}$ \\
\hline $\mathrm{ADV}_{\mathrm{t}-1} * \mathrm{LEADER}_{\mathrm{t}}$ & & & & & & $\begin{array}{c}-1.200 * * * \\
(-3.67)\end{array}$ \\
\hline $\mathrm{SIZE}_{\mathrm{t}}$ & $\begin{array}{c}-0.076 * * * \\
(-14.30)\end{array}$ & $\begin{array}{c}-0.076 * * * \\
(-14.20)\end{array}$ & $\begin{array}{c}-0.075^{* * *} \\
(-14.02)\end{array}$ & $\begin{array}{c}-0.075^{* * *} \\
(-14.05)\end{array}$ & $\begin{array}{c}-0.082 * * * \\
(-14.95)\end{array}$ & $\begin{array}{c}-0.082 * * * \\
(-14.99)\end{array}$ \\
\hline $\mathrm{MBt}$ & $\begin{array}{l}0.005 * * * \\
(3.63)\end{array}$ & $\begin{array}{l}0.005 * * * \\
\quad(3.67)\end{array}$ & $\begin{array}{l}0.006 * * * \\
(3.76)\end{array}$ & $\begin{array}{l}0.006 * * * \\
(3.80)\end{array}$ & $\begin{array}{c}0.006 * * * \\
(3.77)\end{array}$ & $\begin{array}{c}0.006 * * * \\
(3.93)\end{array}$ \\
\hline $\mathrm{LOSS}_{\mathrm{t}}$ & $\begin{array}{c}-0.406 * * * \\
(-22.03)\end{array}$ & $\begin{array}{c}-0.406^{* * * *} \\
(-22.05)\end{array}$ & $\begin{array}{c}-0.402 * * * \\
(-21.85)\end{array}$ & $\begin{array}{c}-0.402 * * * \\
(-21.87)\end{array}$ & $\begin{array}{c}-0.396 * * * \\
(-21.49)\end{array}$ & $\begin{array}{c}-0.392 * * * \\
(-21.36)\end{array}$ \\
\hline $\mathrm{AGE}_{\mathrm{t}}$ & $\begin{array}{l}0.001 \\
(1.40)\end{array}$ & $\begin{array}{l}0.001 \\
(1.38)\end{array}$ & $\begin{array}{l}0.001 \\
(0.97)\end{array}$ & $\begin{array}{l}0.001 \\
(1.13)\end{array}$ & $\begin{array}{l}0.001 \\
(0.72)\end{array}$ & $\begin{array}{l}0.001 \\
(0.71)\end{array}$ \\
\hline Constant & $\begin{array}{c}1.787 * * * \\
(52.36)\end{array}$ & $\begin{array}{c}1.780 * * * \\
(53.44)\end{array}$ & $\begin{array}{c}1.625 * * * \\
(29.09)\end{array}$ & $\begin{array}{c}1.726 * * * \\
(52.90)\end{array}$ & $\begin{array}{c}1.755 * * * \\
(56.16)\end{array}$ & $\begin{array}{c}1.731 * * * \\
(55.12)\end{array}$ \\
\hline Observations & 35,812 & 35,812 & 35,812 & 35,812 & 35,812 & 35,812 \\
\hline $\begin{array}{l}\text { R-squared } \\
\text { F-value }\end{array}$ & $\begin{array}{c}0.163 \\
240.11 * * *\end{array}$ & $\begin{array}{c}0.164 \\
209.12 * * *\end{array}$ & $\begin{array}{c}0.164 \\
239.35 * * *\end{array}$ & $\begin{array}{c}0.165 \\
210.82 * * *\end{array}$ & $\begin{array}{c}0.166 \\
243.31 * * *\end{array}$ & $\begin{array}{c}0.168 \\
217.64 * * *\end{array}$ \\
\hline \multicolumn{7}{|c|}{$\begin{array}{l}*, * *, * * * \text { indicates } 10 \%, 5 \% \text {, and } 1 \% \text { significance, respectively. The t-values are computed using robust standard errors for firm } \\
\text { clusters. SALES = sales of a firm in year t; ADV = advertising expenditures in year t-1; ROA = return on assets; SIZE = natural } \\
\text { logarithm of firm's total assets; MB = market value of equity / book value of equity; LOSS = } 1 \text { if income before extraordinary } \\
\text { items is less than zero, and } 0 \text { otherwise; HHI = the sum of the squared market shares in an industry; CONC = four-firm } \\
\text { concentration ratio measured by sales in an industry; LEADER = indicator variable equal to } 1 \text { if the firm is one of the largest four } \\
\text { firms in an industry; HIGH_COMP = } 1 \text { if HHI is higher than median value, and } 0 \text { otherwise; HIGH_CONC = } 1 \text { if CONC is } \\
\text { higher than median value, and } 0 \text { otherwise. More detailed variable definitions are in Appendix A. }\end{array}$} \\
\hline
\end{tabular}


Table 6 reports the results of the regression equation (2) for the remaining two product market competition measures. In Model (2), the coefficient of an interaction term, ADVt-1 *HIGH_MARGINt, is insignificant. Thus, we do not make any conclusion whether firms in the market with more substitutable products invest advertising to increase sales or not. In Model (3), insignificant coefficient of (ENTCOST seem to suggest that the threat from outside rivals has no effect on advertising-sales relationship. However, the coefficient of an interaction term, $\mathrm{ADV}_{\mathrm{t}-1}$ *HIGH_COSt $t_{t}$, in Model (4) is negative and significant. That is, when advertising is examined interactively with potential competition, their market may consider advertising less effective in generating more sales. From Table 6, we interpret that advertising effect on sales increase is low when the initial investment to enter the market is high and the market has fewer potential rivals.

In sum, we found that four out of five interactions indicate that advertising effect is high (low) when the market competition is high (low). Therefore, our analysis of the interactions of product market competition generally supports hypothesis 2 .

TABLE 6

Influence of product market competition from potential rivals and product substitutability on the effect of Advertising Expenditures on Sales Growth

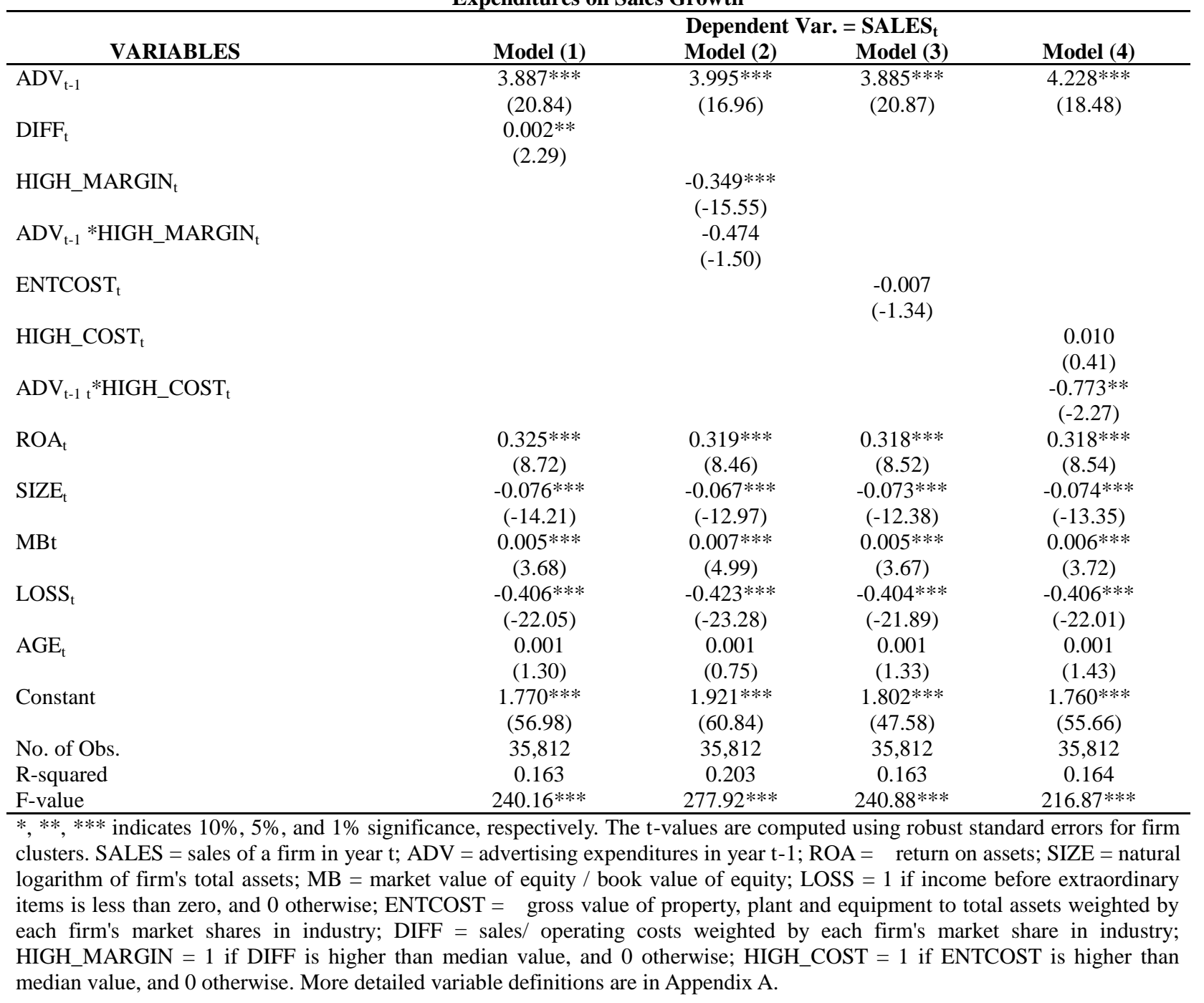




\subsection{Summary of the multiple regression analyses}

- Increasing advertising expenditures increases sales in the subsequent year (Hypothesis 1 is supported)

- $\quad$ The effect of advertising expenditures on sales increases as PMC increases (Hypothesis 2 is supported)

- The effect of advertising expenditures on sales increases as the market is close to perfect competition

- The effect of advertising expenditures on sales decreases as few firms dominates a market

- The effect of advertising expenditures on sales decreases as a firm is one of the four largest firms

- The effect of advertising expenditures on sales increases as the initial investment to enter the market increases

- The effect of advertising expenditures on sales increases as the market has fewer potential rivals

TABLE 7

\begin{tabular}{|l|l|l|}
\hline \multicolumn{1}{|c|}{ Hypothesis Testing } & \multicolumn{1}{c|}{ Empirical Findings } & \multicolumn{1}{c|}{ Result } \\
\hline Hypothesis 1 & $\begin{array}{l}\text { Sales increase when advertising } \\
\text { expenditures increase }\end{array}$ & Very strongly supported \\
\hline Hypothesis 2 & $\begin{array}{l}\text { The effect of advertising expenditures on } \\
\text { sales increases when the product market } \\
\text { competition increases. }\end{array}$ & Strongly supported \\
\hline
\end{tabular}

\section{DISCUSSION}

\subsection{Research results' response to research objectives and the level of support of the initial assumptions}

We aim to address two questions in the present work: (1) whether advertising expenditures increase sales in the subsequent year and (2) whether the effect of advertising expenditures on sales is influenced by PMC. Our analysis of the financial data for 6018 firms for 14 years shows that advertising is effective, in particular, when the market is highly competitive, supporting two hypotheses strongly.

\subsection{Deviations from expected results}

Although PMC influences the relationship between advertising expenditures and sales, we also conjecture that sales increase through advertising investment will saturate at some point. That is, the effect of advertising expenditures on sales will start diminishing if a firm overinvests in advertising. As a supplemental test, we examine whether the relationship between advertising expenditures and sales is linear or not by including a square value of advertising expenditures as an additional independent variable in our regression model (1) in section 3.

Table 7 reports the result of concavity test of advertising expenditures on sales. The coefficient of ADV is positive and significant, but the coefficient of SQ_ADV is negative and statistically significant at the $1 \%$ level after controlling for all five measures of PMC. This result indicates that the relationship between advertising expenditures and sales is not linear but concave. It would be interesting to find out a point of concavity, but it is difficult to find an optimal level of advertising expense for thousands of firms because each firm operates in a unique environment. 
TABLE 8

Test of Concavity of Advertising Expenditures on Sales

\begin{tabular}{|c|c|c|c|c|c|}
\hline \multirow[b]{2}{*}{ VARIABLES } & \multicolumn{5}{|c|}{ Dependent Var. $=$ SALES $_{t}$} \\
\hline & Model (1) & Model (2) & Model (3) & Model (4) & Model (5) \\
\hline $\mathrm{ADV}_{\mathrm{t}-1}$ & $\begin{array}{c}4.455 * * * \\
(22.38)\end{array}$ & $\begin{array}{c}4.471 * * * \\
(22.36)\end{array}$ & $\begin{array}{c}4.462 * * * \\
(22.38)\end{array}$ & $\begin{array}{c}4.464 * * * \\
(22.37)\end{array}$ & $\begin{array}{c}4.470 * * * \\
(22.33)\end{array}$ \\
\hline SQ_ADV ${ }_{t-1}$ & $\begin{array}{c}-0.009 * * * \\
(-8.57)\end{array}$ & $\begin{array}{c}-0.009 * * * \\
(-8.72)\end{array}$ & $\begin{array}{c}-0.009 * * * \\
(-8.47)\end{array}$ & $\begin{array}{c}-0.009 * * * \\
(-8.51)\end{array}$ & $\begin{array}{c}-0.009 * * * \\
(-8.76)\end{array}$ \\
\hline $\mathrm{ROA}_{\mathrm{t}}$ & $\begin{array}{c}0.319 * * * \\
(8.57)\end{array}$ & $\begin{array}{c}0.320 * * * \\
(8.58)\end{array}$ & $\begin{array}{c}0.315 * * * \\
(8.43)\end{array}$ & $\begin{array}{c}0.320 * * * \\
(8.60)\end{array}$ & $\begin{array}{c}0.318 * * * \\
(8.55)\end{array}$ \\
\hline $\mathrm{SIZE}_{\mathrm{t}}$ & $\begin{array}{c}-0.062 * * * \\
(-11.00)\end{array}$ & $\begin{array}{c}-0.060 * * * \\
(-10.69)\end{array}$ & $\begin{array}{c}-0.059 * * * \\
(-9.73)\end{array}$ & $\begin{array}{c}-0.062 * * * \\
(-10.92)\end{array}$ & $\begin{array}{c}-0.067 * * * \\
(-11.66)\end{array}$ \\
\hline $\mathrm{MBt}$ & $\begin{array}{c}0.007 * * * \\
(4.48)\end{array}$ & $\begin{array}{c}0.007 * * * \\
(4.65)\end{array}$ & $\begin{array}{c}0.007 * * * \\
(4.51)\end{array}$ & $\begin{array}{c}0.007 * * * \\
(4.53)\end{array}$ & $\begin{array}{c}0.007 * * * \\
(4.66)\end{array}$ \\
\hline $\operatorname{LOSS}_{\mathrm{t}}$ & $\begin{array}{c}-0.403 * * * \\
(-21.94)\end{array}$ & $\begin{array}{c}-0.399 * * * \\
(-21.76)\end{array}$ & $\begin{array}{c}-0.401 * * * \\
(-21.82)\end{array}$ & $\begin{array}{c}-0.403 * * * \\
(-21.97)\end{array}$ & $\begin{array}{c}-0.392 * * * \\
(-21.39)\end{array}$ \\
\hline $\mathrm{AGE}_{\mathrm{t}}$ & $\begin{array}{c}0.003 * * * \\
(2.62)\end{array}$ & $\begin{array}{c}0.002 * * \\
(2.19)\end{array}$ & $\begin{array}{c}0.003 * * \\
(2.57)\end{array}$ & $\begin{array}{c}0.003^{* *} \\
(2.55)\end{array}$ & $\begin{array}{c}0.002 * \\
(1.95)\end{array}$ \\
\hline $\mathrm{HHI}_{\mathrm{t}}$ & $\begin{array}{l}-0.025 \\
(-0.68)\end{array}$ & & & & \\
\hline $\mathrm{CONC}_{\mathrm{t}}$ & & $\begin{array}{c}0.191 * * * \\
(3.38)\end{array}$ & & & \\
\hline DIFF $_{t}$ & & & $\begin{array}{l}-0.005 \\
(-1.08)\end{array}$ & & \\
\hline ENTCOST $_{t}$ & & & & $\begin{array}{c}0.002 * * \\
(2.04)\end{array}$ & \\
\hline LEADER $_{t}$ & & & & & $\begin{array}{c}0.114 * * * \\
(5.05)\end{array}$ \\
\hline Constant & $\begin{array}{c}1.686 * * * \\
(47.20)\end{array}$ & $\begin{array}{c}1.510 * * * \\
(26.72)\end{array}$ & $\begin{array}{c}1.699 * * * \\
(41.94)\end{array}$ & $\begin{array}{c}1.674 * * * \\
(50.36)\end{array}$ & $\begin{array}{c}1.655^{* * * *} \\
(49.76)\end{array}$ \\
\hline Observations & 35,812 & 35,812 & 35,812 & 35,812 & 35,812 \\
\hline R-squared & 0.170 & 0.171 & 0.170 & 0.170 & 0.173 \\
\hline F-value & $220.49 * * *$ & $220.70 * * *$ & $221.83 * * *$ & $220.73 * * *$ & $224.52 * * *$ \\
\hline
\end{tabular}

$*, * *, * * *$ indicates $10 \%, 5 \%$, and $1 \%$ significance, respectively. The t-values are computed using robust standard errors for firm clusters. SALES = sales of a firm in year $\mathrm{t}$; ADV = advertising expenditures in year $\mathrm{t}-1$; SQ_ADV = square of advertising expenditures in year $\mathrm{t}-1 ; \mathrm{ROA}=$ return on assets; $\mathrm{SIZE}=$ natural logarithm of firm's total assets; $\mathrm{MB}=$ market value of equity / book value of equity; LOSS = 1 if income before extraordinary items is less than zero, and 0 otherwise; HHI = the sum of the squared market shares in an industry; $\mathrm{CONC}=$ four-firm concentration ratio measured by sales in an industry; LEADER = indicator variable equal to 1 if the firm is one of the largest four firms in an industry; ENTCOST = gross value of property, plant and equipment to total assets weighted by each firm's market shares in industry; DIFF = sales/ operating costs weighted by each firm's market share in industry. More detailed variable definitions are in Appendix A.

\subsection{Theoretical implications}

The present work contributes to the advertising literature in three ways. First, we show that advertising effect depends on market variables. Although some prior work suggests that firm variables such as firm size or branding strategy influence advertising effect, it has not been examined whether market variables influence it (Chauvin and Hirschey 1993; Rao et al. 2004). Secondly, we demonstrate that product market competition determines advertising effect. In the prior work, researchers report that the effect of product market competition on sales or values is unclear or insignificant (Hirschey and Weygandt 1985; Lustgarten and Thomadakis 1987) or they try to control the effect of product market competition (Conchar et al. 2005). Finally, we incorporate multiple proxies of product market competition. Most prior work studying market competition concentrates on industry concentration and measures it using a single measure, Herfindahl-Hirschman Index. We include two additional measures to understand the competitiveness of the existing market more deeply, and further include two additional measures to take into account potential competitiveness and product substitutability (Karuna 2007). Doing so deepens our understanding of how product market competition influences advertising effect. 


\subsection{Practical implications}

The present work provides practical implications to advertising managers as well. First, our findings suggest that managers do not have to doubt their decisions to invest into advertising regardless of industries (Tellis and Weiss 1995). According to Table 4, advertising expenditures lift sales in every single industry from mining and construction industries and manufacturing industries to services, retail, and transportation industries. However, our supplemental findings remind managers that increasing advertising expenditures is not a silver bullet; doing so continuously backfires after some points and, therefore, they should carefully conduct the cost-benefit analysis of advertising expenditures. Finally and most importantly, managers should identify the degree to which their market is competitive in order to make more informed decisions whether they should invest into advertising or not. If their market is highly competitive, they may consider increasing advertising expenditures in order to increase sales in the short-term. If this is not the case, they may benefit more by allocating their resources into other activities such as R\&D.

\subsection{Further research and limitations}

Every work has its own limitations and the present work is not exceptional. First, we do not consider that product market competition is shaped by advertising expenditures; instead, we simply assume that it is determined as an upper level market structure. However, some prior work demonstrates that how much a firm spends on advertising may shape how competitive its market is (Eckard 1987). Therefore, researchers need to examine the dynamics between advertising expenditures and product market competition in the future in order to clarify the causal relationship between them. Secondly, we do not consider firm value but concentrate on sales exclusively. However, much recent work demonstrates that increasing advertising expenditures do not necessarily increase sales but increase the stock prices or the values of a firm (Rao et al. 2004; Srinivasan and Hanssens 2009). In the future, researchers should clarify the conditions when advertising expenditures contribute to the tangible assets such as sales and when they contribute to the intangible assets such as firm values.

\section{ACKNOWLEDGEMENT}

This work was supported by the research program 2012 of Kookmin University in Korea.

\section{AUTHOR INFORMATION}

Yura Kim, Assistant Professor of Accounting, College of Business Administration, Kookmin University, Jeongneung Road 77, Seongbuk-Gu, Seoul 136-702, Korea; E-mail: yurak@kookmin.ac.kr (Corresponding author)

Jaewoo Joo, Assistant Professor of Marketing, College of Business Administration, Kookmin University, Jeongneung Road 77, Seongbuk-Gu, Seoul 136-702, Korea; E-mail: jaewoo@kookmin.ac.kr

\section{REFERENCES}

1. Ben-Zion, U. (1978). The Investment Aspect of Nonproduction Expenditures: An Empirical Test. Journal of Economics and Business, 30 (3), 224-229.

2. Capon, N., Rarley, J. U. \& Hoenig, S. (1990). Determinants of Financial Performance: A Meta Analysis. Management Science, 36 (October), 1143-1159.

3. Chauvin, K. W., \& Hirschey, M. (1993). Advertising, R\&D Expenditures, and the Market Value of the Firm. Financial Management, 22 (Winter), 128-140.

4. Cheng, C. S. A. \& Chen, C. J. P. (1997). Firm Valuation of Advertising Expenditures: An Investigation of Scaler Effects. Management Finance, 23 (10), 41-62.

5. Conchar, M. P., Crask, M. P., \& Zinkhan, G. M. (2005) Market Valuation Models of the Effect of Advertising and Promotional Spending: A Review and Meta-Analysis. Journal of the Academy of Marketing Science, 33 (4), 445-460.

6. $\quad$ Eastman, J., Iyer, R. \& Wiggenborn, J. (2010). The short-term impact of super bowl advertising on stock prices: An exploratory event study. Journal of Applied Business Research, 26(6), 69-84. 
7. Eckard, Jr. E. W. (1987). Advertising, Competition, and Market Share Instability. Journal of Business, 60 (4), 539-552.

8. Fields, L. P., Fraser, D. R., \& Wilkins, M. S. (2004). An investigation of the pricing of audit services for financial institutions. Journal of Accounting and Public Policy, 23, 53-77.

9. $\quad$ Graham Jr., R. C. \& Frankenberger, K. D. (2000). The Contribution of Changes in Advertising Expenditures to Earnings and Market Values. Journal of Business Research, 50, 149-155.

10. Hirschey, M. \& Weygandt, J. J. (1985). Amortization Policy for Advertising and Research and Development Expenditures. Journal of Accounting Research, 23 (Spring), 326-335.

11. Joshi, A. \& Hanssens, D. (2010). The direct and indirect effects of advertising spending on firm value. Journal of Marketing, 74(1), 20-33.

12. Karuna, C. (2007). Industry product market competition and managerial incentives. Journal of Accounting and Economics, 43, 275-297.

13. Keller, K. (1993). Conceptualizing, Measuring, and Managing Customer-Based Brand Equity. Journal of Marketing, 57 (1), 1-22.

14. Lodish, L. M., Abraham, M., Kalmenson, S., Livelsberger, J., Lubetkin, J., Richardson, B., \& Stevens, M. E. (1995). How Advertising Works: A Meta Analysis of 389 Real World Split Cable TV Advertising Experiments. Journal of Marketing Research, 32 (May), 125-139.

15. Luo, X. \& De Jong, P. (2012). Does advertising spending really work? The intermediate role of analysts in the impact of advertising on firm value. Journal of the Academy of Marketing Science, 40(4), 605-624.

16. Meldrum and Fewsmith, Inc (1979). How Advertising in Recession Periods Affects Sales. American Business Press, Inc.

17. Nachum, L. \& Rolle, J. D. (1999). Home Country and Firm-Specific Ownership Advantages: A Study of US, UK and French Advertising Agencies. International Business Review, 8, 633-660.

18. Osinga, E., Leeflang, P., Srinivasan, S. \& Wieringa, J. (2011). Why do firms invest in consumer advertising with limited sales response? A shareholder perspective. Journal of Marketing, 75(1), 109-124.

19. Peles, Y. (1970). Amortization of Advertising Expenditures in the Financial Statements. Journal of Accounting Research, 8 (Spring), 128-137.

20. Rao, Vithala R., Agarwal, M. K., \& Dahlhoff, D. (2004). How is manifest Branding Strategy Related to the Intangible Value of a Corporation? Journal of Marketing, 68 (October), 126-141.

21. Szymnski, D. M., Bharadwaj, S. G., \& Varadarajan, P. R. (1993). An Analysis of the Market ShareProfitability Relationship. Journal of Marketing, 57 (July), 1-18.

22. Tellis, G. \& Weiss, D. (1995). Does Advertising Really Affect Sales? The Role of Measures, Models, and Data Aggregation. Journal of Advertising, 24 (Fall), 1-12.

23. Tikoo, Surinder \& Ebrahim, Ahmed (2010). Financial Markets and Marketing The Tradeoff between R\&D and Advertising During an Economic Downturn. Journal of Advertising Research, 50 (1), 50-56.

24. Vaile, Roland S (1929). The Use of Advertising During Depression. Harvard Business Review, 5, 323-330.

25. Vakratsas, D. \& Ambler T. (1999). How Advertising Works: What do We Really Know? Journal of Marketing, 63 (1), 26-43.

26. Walters, P. G. P., Whitla, P., \& Davies, H. (2008). Global Strategy in the International Advertising Industry. International Business Review, 17, 235-249.

27. Wang, F., Zhang, X. P., \& Ouyang, M. (2009). Does Advertising Create Sustained Firm Value?: The Capitalization of Brand Intangible. Journal of the Academy of Marketing Science, 37 (2), 130-143. 


\section{APPENDIX A.}

\begin{tabular}{|c|c|}
\hline $\begin{array}{l}\text { Variable Definitions } \\
\text { Variable }\end{array}$ & Description \\
\hline SALES & Sales scaled by total asset \\
\hline Adv & Advertising expenditures scaled by total asset \\
\hline MB & Ratio of the market value of equity to the book value of equity \\
\hline SIZE & The natural logarithm of the book value of total asset \\
\hline ROA & Return on assets \\
\hline LOSS & $\begin{array}{l}\text { Indicator variable equal to } 1 \text { if income before extraordinary items is less than or } \\
\text { equal to } 0 \text {, and } 0 \text { otherwise }\end{array}$ \\
\hline AGE & Age of a firm since it appears on Compustat database \\
\hline HHI & $\begin{array}{l}\text { A Herfindhal-Hirschman index computed as the sum of squared market share of } \\
\text { all firms in an industry (4-digit SIC), }\end{array}$ \\
\hline $\mathrm{CONC}$ & $\begin{array}{l}\text { (Four-firm concentration ratio) a portion of sales of four largest firms in the } \\
\text { industry }\end{array}$ \\
\hline LEADER & $\begin{array}{l}\text { equal to } 1 \text { if the firm is one of the largest four firms in industry in terms of total } \\
\text { sales in year } t\end{array}$ \\
\hline ENTCOST & $\begin{array}{l}\text { (Entry costs) natural log of weighted average of property, plant and equipment for } \\
\text { firms in industry weighted by each firm's market share in industry }\end{array}$ \\
\hline DIFF & $\begin{array}{l}\text { (Product substitutability in industry) sales divided by operating costs including } \\
\text { cost of goods sold, selling, general and administrative expenditures and } \\
\text { depreciation }\end{array}$ \\
\hline HIGH_COMP & equal to 1 if $\mathrm{HHI}$ is higher than 1500 , and 0 otherwise \\
\hline HIGH_CONC & equal to 1 if $\mathrm{CONC}$ is higher than median $\mathrm{CONC}$, and 0 otherwise \\
\hline HIGH_MARGIN & equal to 1 if DIFF is higher than median DIFF, and 0 otherwise \\
\hline HIGH_COST & equal to 1 if ENTCOST is higher than median ENTCOST, and 0 otherwise \\
\hline
\end{tabular}

